\title{
EDUARD WIIRALT'S UNKNOWN MATCHBOX PICTURE FROM VIENNA, 24 DECEMBER 1944
}

Eduard Wiiralt (1898-1954) has been the most internationally wellknown Estonian artist of all time. The work of the talented artist has been systematically collected from the beginning, whereas the art collector Alfred Rõude was especially active. ${ }^{1}$ During almost 80 years, Wiiralt's life and oeuvre have been introduced in many books ${ }^{2}$, exhibitions and museums. Therefore, from the viewpoint of art history, only some new and unknown work by Wiiralt may elicit any surprise.

Inspired by Estonian art historian Kaur Alttoa's interest in Eduard Wiiralt's work, the main objective of this article is to introduce a work by Wiiralt, which is little known and belongs to a private collection a matchbox picture created in Vienna on 24 December $1944 .{ }^{3}$ Wiiralt

DOI: https://doi.org/10.12697/BJAH.2017.13.12

Translated by Juta Ristsoo.

1 Mai Levin, “Alfred Rõude sünnipäeval”, Sirp, 15.04.2011.

2 The books that have been published in Estonian include: Rasmus Kangro-Pool, Eduard Viiralt (Tallinn: Kirjastus O/Ü Kultuurikoondis, 1938); Eduard Wiiralt (Stockholm: Eesti Raamat, 1952); Eduard Wiiralt 1898-1954. Mälestusteos (Lund: Eesti Kirjanike Kooperatiiv, 1954); Eduard Viiralt 1898-1954, compiled by Hilja Läti (Tallinn: Eesti NSV Kunst, 1958); Eduard Wiiralt, compiled by Ott Kangilaski (Tallinn: Eesti Riiklik Kirjastus, 1959); Eduard Viiralt 1898-1954, Eduard Viiralti näituse kataloog, compiled by Mai Levin (Eesti NSV Riiklik Kunstimuuseum, 1976); Eduard Viiralt, compiled by Mai Levin (Tallinn: Kunst, 1985); Mai Levin, Eduard Wiiralt 1898-1954 (Tallinn: Eesti Kunstimuuseum, 1998); Mai Levin, Eduard Wiiralt (1898-1954) (Tallinn: Eesti Kunstimuuseum, 2015).

3 Anu Raudsepp's private collection. 


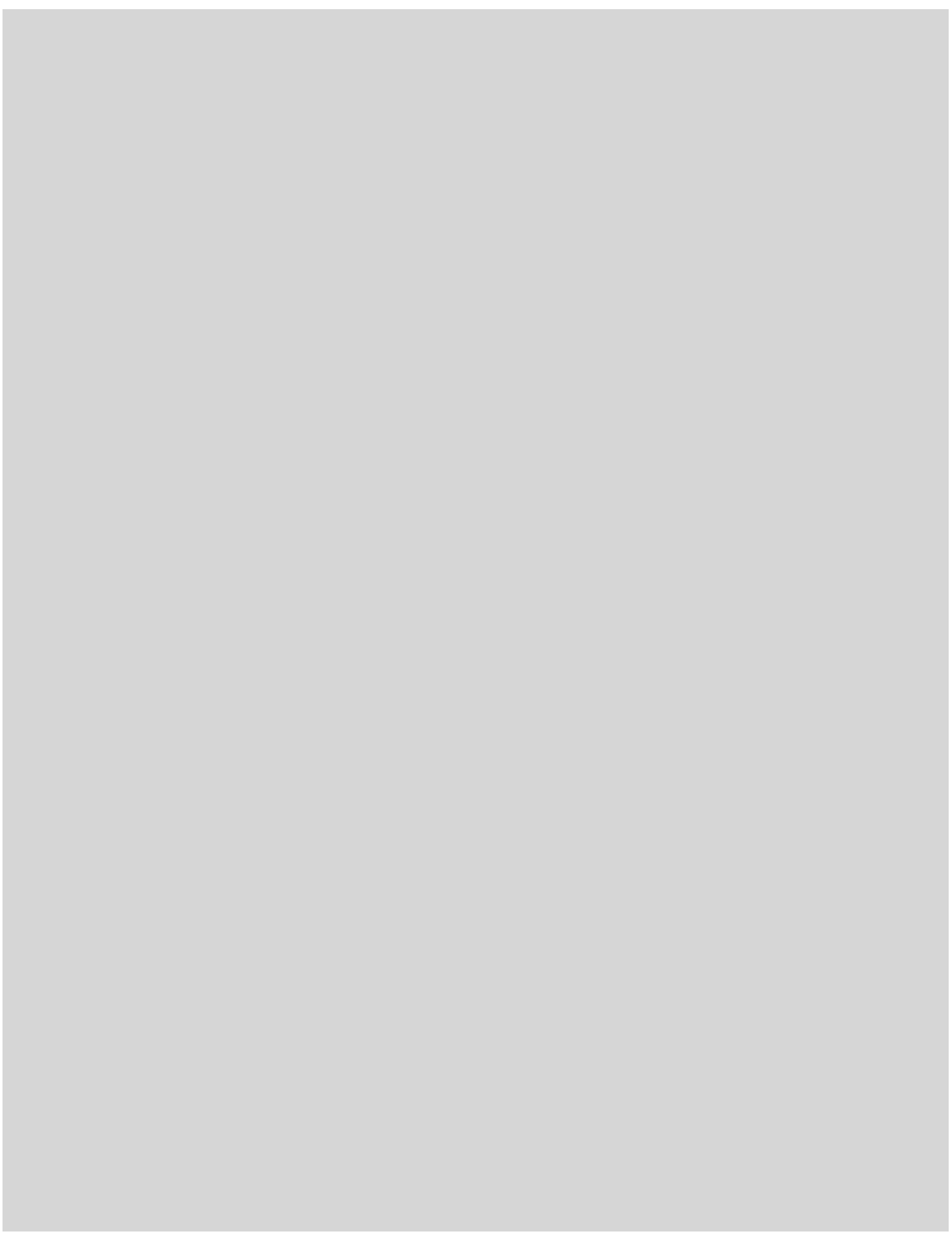

Fig. 1. Eduard Wiiralt working (undated photo). Photo was found from the correspondence of Estonian art historian Armin Tuulse National Archives of Estonia, Tartu. spent most of his life away from Estonia, and lived the longest in Paris. During World War II, he was able to leave Estonia on 28 April 1944, at the end of the German occupation, thanks to an invitation from the Vienna Artists' Society to organise a solo exhibition. The exhibition was open from June $17^{\text {th }}$ to August $1^{\text {st }}$ and included 60 works. ${ }^{4}$ Wiiralt was in Vienna from 30 April 1944 until 6 January $1945^{5}$, when he went to Berlin.

In addition to introducing the new work, the undersigned will also try to supplement the history of Estonian bookplate art, because Wiiralt's matchbox picture was reproduced as a bookplate at the request of its owner. Among Estonian booklovers at home as well as abroad ${ }^{6}$, bookplates have always been valued as the signs of a book's ownership. However, Hanno Lepik, a bookplate enthusiast, believes that Estonian art historians have yet to thoroughly analyse the development of bookplate art. Nevertheless, since 1898 about 50,000 bookplates have been created ${ }^{7}$ and the first Estonian artistic bookplates were made by the famous artist Kristjan Raud. ${ }^{8}$

\section{THE RECEPTION OF EDUARD WIIRALT'S WORK IN OCCUPIED ESTONIA UNTIL THE END OF THE 1950S}

A common belief still exists today that "during the harsh Stalinist years, Wiiralt was declared to be non-existent for Estonia art and he was not spoken about publicly as an artist until after his death". ${ }^{9}$ Upon closer examination it becomes clear that one cannot totally agree with this statement. It's true that Wiiralt was not discussed in the media, and even on the occasion of his $50^{\text {th }}$ birthday in 1948 nothing was written about him in the Estonian cultural press. After his departure from Estonia, his work was only introduced to the public on one occasion. Namely, Eduard Wiiralt's Half-

4 Levin, Eduard Wiiralt (1898-1954), 89.

5 Levin, Eduard Wiiralt (1898-1954), 221

6 See: Paul Ambur, Eesti kunstipärastest eksliibristest (Tallinn: Eesti Riiklik Kirjastus, 1958) Richard Antik, "Eesti kunstipärane exlibris 76 must-valge ja värvilise reproduktsiooniga", Raamatu valgusel, Richard Antik 100: artikleid ja bibliograafia (Tartu: Eesti Kirjandusmuuseum, 2001), 58-75.

7 Hanno Lepik, Eesti eksliibris arvudes (Tallinn: H. Lepik, 2010), 6.

8 Antik, "Eesti kunstipärane eksliibris 76 must-valge ja värvilise reproduktsiooniga", 60 .

9 Levin, Eduard Wiiralt (1898-1954), 7 
Nude (drypoint, 1943) appeared in the Postimees newspaper on 6 May 1944. The publication of this picture (later known as Astrid) a week after Wiiralt's departure was a kind of farewell to the great master. Although, despite the constraints of censorship, the Postimees fleetingly reporting on Estonian cultural events abroad, there was no reporting on the Wiiralt's departure in connection with the opening of art exhibition in Vienna.

Although Wiiralt was ignored in the Stalinist press, it did not mean that he was ignored in the art history being taught in three educational institutions. At the Tartu State University, the Department of Art History was headed by Voldemar Vaga from 1945 to $1950^{10}$, who, among other things, also lectured on Estonian art history, and the volume of which, for example, was 104 hours in $1948 .{ }^{11}$ There is no reason to doubt that Vaga dealt with the work of Eduard Wiiralt during these courses. ${ }^{12}$ Vaga also headed up the Department of Art History at the Tartu State Art Institute until the autumn of $1947,{ }^{13}$ and was succeeded by graphic artist Märt Pukits. ${ }^{14}$ In the file related to the 1949-1951 curricula, the following notes were included on an undated Estonian art history programme called "Estonian Art under the Bourgeois Dictatorship": "The Increasing Importance of Graphic Art: Viiralt. The Multifaceted Visage of his Work".$^{15}$ It is very possible that this programme was already prepared by Vaga. It is important to add that the Tartu State Art Institute was the former Higher Art School Pallas, the first graduates of which in 1924, included Eduard Wiiralt. ${ }^{16}$

Estonian art history was taught at the Tallinn State Institute of Applied Art ${ }^{17}$ by Associate Professor Leo Soonpää. And the subject

10 See more: Mari Nõmmela, Stiiliajaloolise ja marksistliku käsitluse konflikt Voldemar Vaga kunstiajalookirjutuses 20. sajandi II poolel (Tartu: Tartu Ülikooli Kirjastus, 2013).

11 Estonian Historical Archives [Ajalooarhiiv, EAA], 5311-5-44, 19.

12 To date, the author has been unable to find the art history programme for the Tartu State University at the time. It was not among the programmes for the Department and History and Linguistics.

13 National Archives of Estonia [Rahvusarhiiv, ERA], R-1973-1-1. (The minutes for the meetings of the Council of the Tartu State Art Institute from 5 December 1944 to 15 May 1948.)

14 ERA, R-1973-1-1; ERA, R-1973-1-40. (The minutes for the meetings of the Council of the Tartu State Art Institute from 2 June 1948 to 23 November 1950.)

15 ERA, R-1973-1-56, 140-141. (Programmes for the specialities at the Tartu State Art Institute 1949-1951.)

16 Tiina Nurk, Pallas 1919-1940 (Tartu: Eesti Kunstimuuseum, Tartu Kunstimuuseum, 2004), 63-66.

17 Starting in 1951, after the merger with the Tartu State Art Institute, the Tallinn State Art Institute and today the Estonian Academy of Arts. called "Shift toward Realism. Graphic Art" in the art history programme included Wiiralt by name. ${ }^{18}$ Therefore, Wiiralt's creative achievements were publicly discussed with future art historians and artists. Soon many of these students actively participated in publicly recognising Wiiralt, although this did not occur until artist had died in 1954.

The approval for recognising Wiiralt as a bookplate artist had to come from Moscow. Starting in 1954, the art historians planned to introduce Wiiralt at the Estonian SSR Art Decade in Moscow. On 14 May 1954, at a meeting of the art history section, there was a discussion, among other things, about the author sheets, in which Eduard Wiiralt was mentioned as one of the 15 artists. However it's true that the compiler of his author's sheet was the only one that was still undecided.$^{19}$ The next year, a thorough and approving article about Eduard Wiiralt appeared in the cultural newspaper Sirp ja Vasar, which was authored by Enn Põldroos, who was a student at the Estonian State Art Institute at the time, but is a renowned artist today..$^{20}$ On 14 January 1956, the Tallinn State Art Museum again recommended to the Estonian SSR Ministry of Culture that the Wiiralt's artwork be included in the series of author's sheets to be displayed at the Decade, and agreed to be the executor of the project. ${ }^{21}$ The fine arts exhibition at the Estonian SSR Art Decade in Moscow was open from 18 December 1956 to 6 January 195722, and included 18 works by Eduard Wiiralt. ${ }^{23}$ In the exhibition catalogue, Wiiralt was praised as someone whose work had received international recognition..$^{24}$ Only then was the first exhibition of Wiiralt's work organised in Estonia, and this took place at the Tartu State Art Museum in March of 1957. ${ }^{25}$ In 1957, through the writing of Irina

18 ERA, R-1696-1-29, 48, 62, 81. (The calendar schedules, reports, etc. of the Department of Art History, at the Tallinn State Institute of Applied Art, 1946-1950.)

19 ERA, R-1665-1-162. (The minutes of the Art History Section of the Artists' Union of the Estonian SSR, 22 December 1951-10 April 1954.)

20 Enn Põldroos, "Eduard Viiralti loomingust", Sirp ja Vasar, 13.05.1955.

21 ERA, R-1797-1-270, 43. (Correspondence related to the organisation of the All-Soviet Agricultural Exhibition and Estonian Art Decade 11 January-1 December 1956.$)$

22 ERA, R-1797-1-270, 210-211.

23 Выставка Эстонского изобразительного исскусства (Москва, 1956), 50-51.

24 Выставка Эстонского изобразительного исскусства, 7.

25 Hilja Läti, “Ed. Viiralti teoste näitus”, Rahva Hääl, 08.05.1958 
Solomõkova, Wiiralt was included in the history of the Estonian SSR, and called an "outstanding artist who had achieved mature excellence". ${ }^{26}$ It was the custom in the Soviet Union to honour cultural and political figures during their jubilees. In 1958, on Eduard Wiiralt's $60^{\text {th }}$ birthday, he was also remembered and a series of written works appeared, culminating with his monograph. ${ }^{27}$

\section{THE ARRIVAL IN ESTONIA OF EDUARD WIIRALT'S MATCHBOX PICTURE GIRL LOOKING UP IN PRAYER}

It is undoubtedly interesting to know when Wiiralt's original postwar works arrived in Estonia. At the second Wiiralt exhibition that took place at the Tallinn State Art Museum in April of 1958, which included 800 works, only a few reproductions of his post-war works were displayed. ${ }^{28}$

Of Eduard Wiiralt's close relatives, the only living person who could have owned his works as a direct heir was his brother August Wiiralt. In the autumn of 1959, he authorised Alfred Rõude, the owner of Estonia's largest Wiiralt art collection, to deal with his famous brother's legacy, including the payment of royalties due to Eduard Wiiralt based on his copyright. August Wiiralt granted Rõude the right "to administer and dispose of all his assets, no matter where they are located or what they are comprised of". ${ }^{29}$ Thereby, it is very possible that the Tallinn State Art Museum was also interested in acquiring Wiiralt's works. The reason for their interest may have been the fact that they had started to buy Wiiralt's earlier works from Rõude in the second half of the 1950s. ${ }^{30}$

Based on the above, it is very probable that Eduard Wiiralt's matchbox picture that is introduced in this article was the artist's first post-war work to reach Estonia. The communications between the Estonians at home and abroad had only recently become more

26 Eesti NSV ajalugu (kõige vanemast ajast tänapäevani), ed. by Gustav Naan (Tallinn: Eesti Riiklik Kirjastus, 1957), 503.

27 Eduard Viiralt 1898-1954, compiled by Hilja Läti (Tallinn: Eesti NSV Kunst, 1958).

28 “Näitused", Kunst, 1 (1959), 72

29 ERA, R-5078-1-3447, 1p-2.

30 Levin, "Alfred Rõude sünnipäeval", 17.

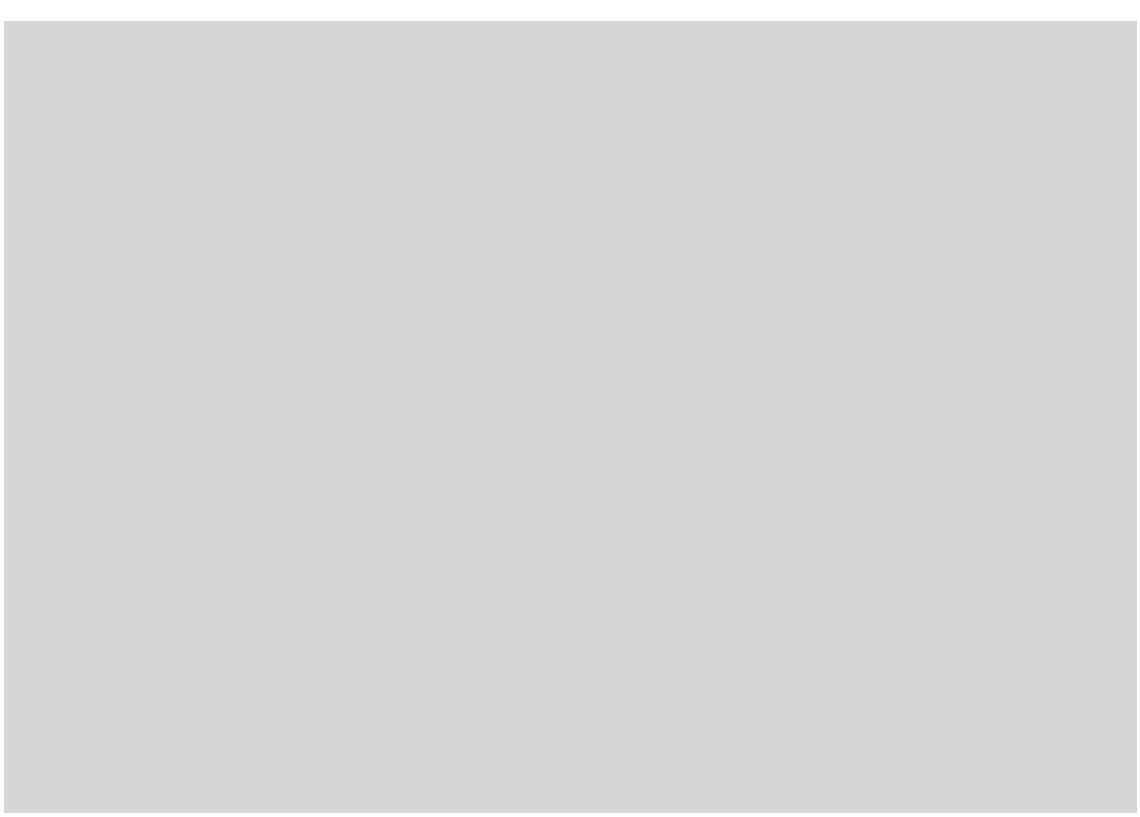

Fig. 2. Eduard Wiiralt, Agathe Veeber and Märt Roosma in Vienna on 22 August 1944 Art Museum of Estonia, Tallinn.

active in the freer atmosphere that prevailed after the $20^{\text {th }}$ Congress of the CPSU (1956). ${ }^{31}$ Letters must have been sent to and from Estonia before that, but there is little evidence of this. Based on the experience of the author's family, correspondence with relatives in exile was conducted from 1946 to 1948 and then again starting in the mid1950s. ${ }^{32}$ At the same time, considering continued Soviet censorship and correspondence control, there was no guarantee that valuable parcels would ever reach their addressees.

On 15 February 1959, an Estonian man named Kalju ${ }^{33}$, who had left Estonia in fear of the Soviet occupation, sent a letter to Ilse Veemees $(1925-2016)^{34}$, who had stayed in Estonia, which contained an Eduard Wiiralt matchbox picture $(3,9 \times 5,2$, paper, ink, dated 24 December 1944). They had reconnected through correspondence when Ilse

31 Tiina Saluvere, "Dialoogi võimalikkusest: variante Nõukogude Eesti ja eksiili suguluseks kultuuriloolise arhiivi kogude põhjal", Adressaadi dünaamika ja kirjanduse pingeväljad (Tartu: Tartu Ülikooli Kirjastus, 2016), 226.

32 Anu Raudsepp's private collection.

33 Kalju's surname is unknown to the author.

34 Ilse Veemees was the aunt of Anu Raudsepp. 
Veemees, who was deported to Siberia in 1949, returned home in 1957. From the letter it becomes clear that Ilse Veemees had previously sent Kalju books from Estonia. The letter said: "Interesting that a few days before your package arrived, I was thinking I should find a copy of Gösta Berling's Saga. ${ }^{35}$ It would be fun to read it again after such a long time. Therefore I was joyfully surprised when I found the Gösta among the book about Wiiralt ${ }^{36}$ and among the blinds ${ }^{37}$. I've been interested in Wiiralt ever since I was in school, but I don't have anything but a copy of Eduard Wiiralt printed in Sweden ${ }^{38}$. The format is large but the contents are slim. The one you sent is much better. I am sending you my only very original Wiiralt original, because all of Wiiralt's work, be it just a girl looking upward in prayer drawn on the back of a matchbox, due to the lack of paper, belongs to the homeland, where Wiiralt always belonged in his heart." Wiiralt's Viennese matchbox picture was a special gift to a very special person.

\section{EDUARD WIIRALT'S VIENNESE MATCHBOX PICTURES}

The largest collection of Eduard Wiiralt's works is located at the Art Museum of Estonia, and Wiiralt's Viennese matchbox pictures are accessible to everyone in their online digital collection. ${ }^{39}$ These sketches arrived in Estonia in 1988 as a gift from artist Märt Roosma, an exile Estonian. ${ }^{40}$ Roosma arrived in Vienna on 23 June $1944^{41}$ and systematically collected Wiiralt's work, including the matchbox pictures. ${ }^{42}$ There are a total of 66 matchbox pictures in the Art Museum of Estonia collection: 43 are dated between 9 August 1944 and 13 January 1945; five between 1944 and 1945; four are dated 1944 and 14 are undated.

35 Selma Lagerlöf, Gösta Berlingi saaga (first Estonian translation 1939, second 1958).

36 Eduard Viiralt 1898-1954, compiled by Hilja Läti (Tallinn: Eesti NSV Kunst, 1958).

37 Juhan Smuul, Kirjad sõgedate külast. [Letters from the Village of Blinds] (Tallinn: Eesti Riiklik Kirjastus, 1955).

38 Eduard Wiiralt 1898-1954. Mälestusteos (Lund: Eesti Kirjanike Kooperatiiv, 1954).

39 Art Museum of Estonia. Digital Collection, https://digikogu.ekm.ee/ [viewed 03.05.2017].

40 Mai Levin, "Märt Roosma kingitus", Kogude teatmik. Artiklid 1988 (Tallinn: Eesti Kunstimuuseum, 1988), 56-71.

41 Levin, Eduard Wiiralt 1898-1954 (1998), 89

42 Levin, "Märt Roosma kingitus", 60.
Wiiralt's Viennese matchbox pictures have yet to be researched. Art historian Mai Levin noted the following in 1988: "As with the drawings of nudes, Viiralt's sketches can be viewed separately as artistically charming miniatures. Basically they are heads, some are caricaturised, and some idealised." ${ }^{\prime \prime 3}$

Most of the sketches have been drawn in ink on lilac matchbox bottoms, fewer on white ones. The largest group of sketches is comprised of women's portraits, including one semi-nude (26 November 1944). There are also several portraits of men. There are few of girls and boys, and one of a child (Round Child's Head 11 December 1944). The one undated sketch of a tiger is an exception.

The faces portrayed on Eduard Wiiralt's matchbox pictures are, similarly to his other portraits, very expressive. In the case of these pictures, the great difference between the male and female portraits stands out. The men depicted on the matchbox pictures from Wiiralt's Vienna period are often ugly or grotesque, for example Bone in the Mouth $^{44}$ (10 September 1944), Old Man's Head Screaming (22 November 1944), Man Picking his Now (September 1944), Tongue Sticking Out (1944-1945), and Man Smoking Two Pipes (1944), etc. On the other hand, the women are beautiful and modest, for instance, the pensive (undated) With a Lowered Gaze (1944-1945), Smiling (5 November 1944), With a Straw Hat (22 December 1944), With a Veil (18 October 1944), With a Polka-dot Scarf (10 September 1944), With Half-closed Eyes (25 December 1944), etc. In a way, Wiiralt's Viennese pictures reflect the meaning of 1944 for Estonians - grotesque, with much sadness and little joy.

The sketches in the Art Museum of Estonia collection also include a matchbox picture dated 24 December 1944 Vienna. It is called Woman's Face with a Birthmark, which resembles the Girl Looking Up in Prayer dated 24 December 1944. It is possible that Märt Roosma later sold a picture with the same date, but it is impossible, as well as unnecessary, to prove it.
43 Ibidem.

44 Here and hereafter the titles of the matchbox pictures are provisional. 


\section{A BOOKPLATE FROM EDUARD WIIRALT'S}

\section{MATCHBOX PICTURE}

Ilse Veemees valued the matchbox picture by Wiiralt gifted to her so much that she decided to have a bookplate made of it. For her, like for many other Estonians in the Soviet era, books were a means of expressing resistance and a special bookplate added even more value.

The late 1950s was a time when the popularity of bookplates kept increasing in Estonia. The local golden age of bookplates is considered to be the period between 1957 and 1999, when 30,404 bookplates were produced. ${ }^{45}$ Although after the war it was declared "now that we have started a new phase of creation, each booklover and book owner should put their library in order and set a goal of labelling their collections with artistic bookplates" ${ }^{\prime \prime 6}$, creating bookplates was not revived until the Soviet era was established, and they did not start to be talked about until 1956.77 On 1 June 1957 an exhibition of bookplates opened at the Tallinn State Art Museum, where almost 700 bookplates were on display. ${ }^{48}$ In his review, art critic Boris Bernstein called bookplates "the most intimate, reserved genre of graphic art, which inspires fantasy and allows one to search for unexpected compositional and decorative solutions". Among others, he highlighted the bookplates created by Eduard Wiiralt. ${ }^{49}$

The words Ex Libris and the owner's name for Ilse Veemees's bookplate, with the matchbox design and Eduard Wiiralt's picture, were designed by Harald Siim, an amateur bookplate designer. Although the picture was already signed by Eduard Wiiralt, he also wrote his name $-\mathrm{H}$. Siim - under the picture. He usually used the initials HS as his signature. ${ }^{50}$ The Main Administration for Literary and Publishing Affairs of the Estonian SSR granted permission for the bookplate to be printed on 23 December $1960 .^{51}$

45 Lepik, Eesti eksliibris arvudes, 8.

46 "Ex Libris", Sirp ja Vasar, 25.05.1946.

47 Paul Ambur, "Minu raamat", Nõukogude Naine, 10 (1956), 21-22.

48 Lehti Viiroja, "Eksliibriste näitus", Noorte Hääl, 02.06.1957.

49 Boris Bernstein, "Elav kunst", Sirp ja Vasar, 26.07.1956.

50 Eesti eksliibriste loetelu. Lisa 1, Autorid, compiled by Hanno Lepik (Tallinn: H. Lepik, 2009), 32.

51 Anu Raudsepp's private collection

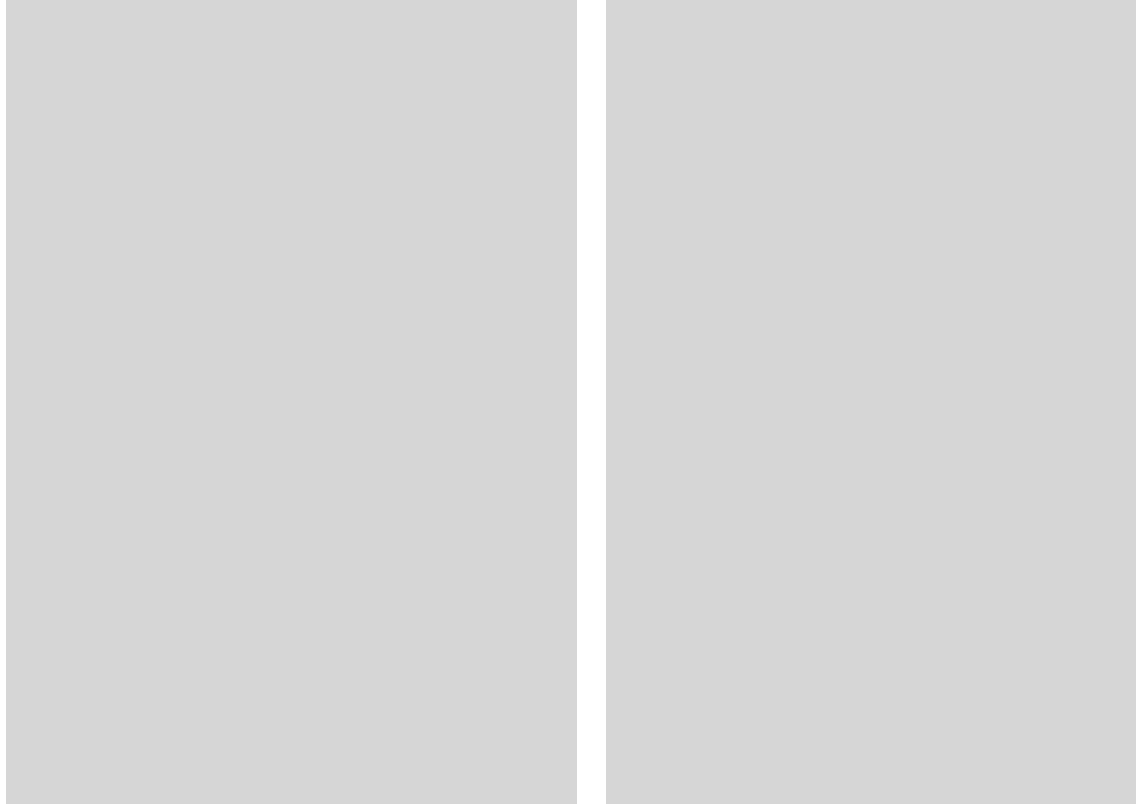

Fig. 3. Ilse Veemees's bookplate based on Eduard Wiiralt's matchbox picture Girl Lookin Up in Prayer. Anu Raudsepp's private collection.

Fig. 4. The second version of Ilse Veemees's bookplate. Anu Raudsepp's private collection

At that time, bookplates were printed at the Hans Heidemann printing house ${ }^{52}$ in Tartu, where Ilse Veemees worked as a proofreader Before being printed, the type on the bookplate was significantly simplified. It is not known who made the changes, but they differ significantly from Harald Siim's style, so it is possible that he did not. Bookplates were published in large runs in four different colours: on lilac, yellow, green and white backgrounds. ${ }^{53}$

Eduard Wiiralt is known to have created seven bookplates: for foreigners in 1929 (Bernard Davis, May W. Wise), 1930 (Samuel Nellis) and 1936 (Dutch art collector Ans van der Kuylen); ${ }^{54}$ for Estonians in 1918 (theatrical figure Taavet Mutso) and in 1936, two bookplates for politician and diplomat Kaarel Robert Pusta. ${ }^{55}$ Several other Estonians

52 Today the Greif printing house.

53 Anu Raudsepp's private archive. The owners name has been cut off the bookplate.

54 Ambur, Eesti kunstipärastest eksliibristest, 235.

55 Ibidem. 
had wanted Wiiralt to create bookplates for then, but he refused. For example, Luise Sider, who was studying in Paris, wrote in her diary that the she had tried to get the artist to create a bookplate for her, but was unsuccessful. ${ }^{56}$

Ilse Veemees's bookplate is exceptional and the evident contribution made by Harald Siim, its official author, is just adding his name and date - H. Siim. 60 - to Eduard Wiiralt's picture.

\section{CONCLUSION}

Ott Kangilaski has said that Eduard Wiiralt "as a person was very silent, all the more because his work spoke for him. There are few people who understand everything that he recounted to us in his pictures. However, the panorama of his oeuvre is wide ranging, and everyone who wants can find a pleasing segment for themselves." ${ }^{57}$ The impact of art on our everyday lives is greater than we admit. The changes that occur in society and the moods that accompany them can be documented by art. From the picture Girl Looking Up in Prayer (Vienna, 24 December 1944), drawn on the Christmas Eve of the year when the hope of restoring Estonia's independence was lost, one can surmise the artist's belief and hope that his beloved Estonia would someday become free again.
Anu Raudsepp: Eduard Witralt's Unknown Matchbox Picture From Vienna, 24 December 1944

Keywords: Estonian art in exile; Bookplate; EX Libris; Graphics; EDUARD WiIRALT

\section{SUMMARY}

The main objective of the article is to introduce the matchbox picture called Girl Looking Up in Prayer created in Vienna on 24 December 1944 and the bookplate based thereon that was produced in Estonia in 1960. In addition, based on archival sources, an explanation is provided of the reception of Eduard Wiiralt's work in occupied Estonia until the end of the 1950s.

Despite the common belief that Wiiralt was totally ignored during the Stalinist period in Estonia, he was still included in the art history curricula of the official schools of higher education. Many of the students at that time were soon actively helping to restore public recognition to Wiiralt, which occurred after the artist's death in 1954. The introduction of Wiiralt's oeuvre in Estonia was preceded by an exhibition in Moscow in 1956. It is possible that the matchbox picture that was sent to Estonia in a letter on 15 February 1959 was not the first original post-war work by Wiiralt to arrive here. The owner had the picture made into a bookplate that was produced in a large run. Eduard Wiiralt himself is known to have made seven bookplates between 1918 and 1936.

It is also possible to document the changes that have occurred in society and the moods of the times through art. From the matchbox picture that Wiiralt drew on Vienna on Christmas Eve in 1944, the year that Estonia lost its independence, one can surmise the artist's belief and hope that his beloved Estonia would someday become free again.

\section{CV}

Anu Raudsepp, PhD (b. 1962) is working as an Associate Professor at the Institute of History and Archaeology of University of Tartu. Her main fields of research include the history of the Stalinist Era, and textbook research.
56 Mart Lepp, Eduard Wiiralt. Kolmteist gravüüri ja joonistust Mart Leppa kunstikogust linn: Mart Lepp, 1995)

57 Ott Kangilaski, “Äärjooni Eduard Viiralti elust ja loomingust”, Looming, 10 (1956), 1508 
